\title{
Towards inclusive environmental governance in the Arganeraie Biosphere Reserve, Morocco
}

\author{
Mari-Carmen Romera, Feliu López-i-Gelats, Pablo Dominguez, Said Boujrouf \& Roser Maneja
}

Keywords: argan, social-ecological systems, natural protected areas, post-normal science, ethnography, stakeholder analysis, social learning

\section{Abstract}

Arganeraie Biosphere Reserve (ABR) in Morocco was established in 1998. Today the reserve covers 2.5 million hectares and more than 3 million people and, as such, it has been a complex social-ecological system to govern. Authors draw on postnormal conservation science and environmental governance studies to investigate environmental governance processes within the $A B R$ and shed light on their outcomes and challenges to date.

First, authors analyse how Moroccan institutions are managing this vast territory. Second, we look at perceptions of an extended peer community of decision-makers. This research adds an empirical case study to the North African region and addresses two main weaknesses of UNESCO Biosphere Reserves worldwide: 1) effective governance and 2) shortcomings in their implementation.

Through an ethnographic approach, we are able to point out how low strategic priority and a weak political will regarding the $A B R$ may be hindering inclusive environmental governance. The authors suggest some key aspects for improving the existing governance system; various baseline needs and barriers that may be addressed in advance; a set of drivers, and several proposals for inclusive governance in the ABR. This study should prompt academia, policy- and decision-makers to identify and enhance synergies that allow for a shared vision of their territory.
Profile

Protected area

Arganeraie Biosphere

Reserve

Mountain range

High Atlas and Anti-

Atlas Mountains

Country

Morocco

\section{Introduction}

There is wide consensus pointing to the benefits for local populations of natural protected areas being run under co-management schemes (e.g. Berkes et al. 2003; Holmes 2008; Brunson 2012). However, the capacity of developing sound governance systems is key to the success of these initiatives. Ison and Wallis (2017) stress that inclusiveness in environmental governance is critical. Brunson (2012) states that best outcomes are dependent on societal values and interests and the capacity of governance systems to include them. In line with this, following Funtowicz and Ravetz (1993), many scholars argue for a postnormal conservation approach (Buschke et al. 2019; Rose 2018), embracing complexity, uncertainty and multiple knowledge systems (Holling 2001; Armitage et al. 2011; Tengö et al. 2014).

UNESCO Biosphere Reserves (BRs) are a good domain to test both the existing shortcomings and the main potential of inclusive environmental governance. UNESCO BRs are one of the best-suited institutionalized approaches to deal with this coupled nature-human interface (Batisse 1982; Coetzer et al. 2013). Conceptually, BRs have proven to be a sufficiently inclusive and adaptive model to conservation. When carefully implemented, BRs contribute to the sustainability paradigm shift towards integrating local populations and conservation (Borrini-Feyerabend et al. 2013; Heinrup \& Schultz 2017; Rose 2018). However, this is not always the case, and often a gap persists between what is stated and what actually happens (Ishwaran et al. 2008; Price et al. 2010; Coetzer et al. 2013).

Despite the lack of research in North Africa on this topic (UNESCO 2014; Blanco et al. 2020), shortcomings in the implementation of BRs, challenges for the conservation and management of BRs and other governance weaknesses have been noted in the specialized literature (Table 1) (IUCN 2015; Matar 2015).

Most of the weaknesses shown in Table 1 are visible in the case of Arganeraie Biosphere Reserve (ABR) ${ }^{1}$. So, a deeper understanding of the causes and implications of both the actual governance and the implementation of more inclusive governance is of great relevance for the future of the ABR. This study examines both perceptions and practices that coexist in the ABR with regard to inclusive environmental governance (IEG), preceded by a comprehensive social analysis. The authors adopt the concept of inclusive governance employed by Ison and Wallis (2017) when framing environmental governance (as defined by Lemos \& Agrawal 2006, p. 298). In particular, the authors stress the elements that facilitate the emergence of shared visions among stakeholders about the future of the ABR. Ethnographic methodologies were conducted.

Réserve de Biosphère de l'Arganeraie (RBA) 
Table 1 - Main weaknesses in the governance of North African Biosphere Reserves (BRs) reported in the specialized literature.

\begin{tabular}{|l|}
\hline Arab Biosphere Reserves \\
\hline Communication, cooperation, and collaboration \\
\hline Involvement and participation of local communities \\
\hline Capacity and resources (cross-functional) \\
\hline Understanding and differentiation of the BR concept. \\
\hline Evaluation of BR management \\
\hline Integration and mainstreaming of the MAB program. \\
\hline ArabMAB institutional gaps \\
\hline Moroccan Biosphere Reserves \\
\hline Lack of awareness and communication programmes. Insufficient capacity for programme development. \\
\hline Absence of management and/or coordination structures dedicated to BRs. \\
\hline Lack of coordination between BR managers, local decision-makers, local communities. \\
\hline Weak integration of local populations into BR planning, management and valorisation activities. \\
\hline Lack of mechanisms and processes to encourage local participation in management. \\
\hline Difficulties in the interaction between management and research. \\
\hline Inadequate legal framework \\
\hline Lack of functionality of zoning with dimensions often incompatible with the criterion related to land use planning. \\
\hline Management plans (if they exist) are developed for Protected Areas and do not reflect Man and the Biosphere (MAB) provisions for BRs. \\
\hline Absence of functional MAB Committee (members are volunteers). Networking among BRs is almost non-existent \\
\hline Appropriation of the provisions of the UNESCO MAB programme is difficult. \\
\hline
\end{tabular}

\section{Methodology}

\section{Study area}

The Arganeraie is a meridional forest ecosystem spanning $25000 \mathrm{~km}^{2}$ as a mosaic in south-western Morocco, primarily in the Souss Massa region (together with Essaouira province in the north-west and Guelmim in the south-west). The ABR was selected for its singularity and suitability to explore the issue of IEG in a biodiverse, but complex, social-ecological system designated by UNESCO as BR in North Africa in December 1998.

The ABR covers 2.5 million hectares identified as the distribution area of the argan forest and is home to over 3 million people (DREFLCD-SO 2018). It includes the city of Agadir (420288 inhabitants) and other towns of more than 70000 inhabitants (HCP 2014). The ABR is internationally recognized as a paradigmatic biocultural Moroccan heritage. In parallel with the designation of the Arganeraie as BR, high investments led to the production of argan oil (the Arganeraie's flagship product) becoming a boom sector (Michon et al. 2015). Yet the challenges and stakes of exploiting local resources for the benefit of local development showcased, early on, a high level of complexity and cross-scale contradiction.

The three main historical periods of the $\mathrm{ABR}$ are: 1) $1990-2005$, design of the initial ABR project, nomination and first implementation stage; 2) 2006-2016, an intermediate period comprising the first periodic review; 3) 2017 to the present, second periodic review and current developments.

\section{Data collection}

To identify the key elements for the examination of current environmental governance and to promote IEG in the Arganeraie, an ethnographic approach was implemented. It combines participant observation and interviews with key informants. This approach allowed an in-depth characterization of the coexisting values, worldviews, beliefs, and interests of the extended peer community of decision-makers interacting in the ABR (policymakers, managers, administration officers, scientists, regional authorities, practitioners, and NGOs). Following Beier et al. (2017), the fieldwork was designed to better understand the existing $A B R$ multi-level governance and the multiple experiences, mindsets and interests playing a role in it.

The fieldwork, which was carried out between 2018-2019, was organized in the following steps: (1) presentation and validation of the research design with key local researchers and ABR decision-makers, followed by prospective open interviews $(\mathrm{N}=20)$ with some of them; (2) in-depth semi-structured interviews $(\mathrm{N}=42)$ with members of the extended peer community; and (3) participant observation transversal to previous meetings and interviews.

The ten research-design validation meetings in step one allowed us to consider an inclusive research design and to assess its relevance at the BR level while building trust with participants. This step guaranteed access to the 42 interviewees and high-quality information from interviews due to trust and inclusiveness. Prospective open interviews provided basic information about the ABR and its stakeholders.

All the interviews were conducted face-to-face in French and followed a flexible conversational approach (Moon et al. 2019). They lasted between 60 and $180 \mathrm{~min}$ and took place at the respondent's workplace or in a quiet public location. Interviews were audio-recorded and transcribed for analysis. The main topics discussed in the in-depth semi-structured interviews covered their understandings of a BR, the ABR management model and their perceptions of 
Table 2 - Main topics discussed in the in-depth semi-structured interviews with the extended peer community of decision-makers linked to the Arganeraie Biosphere Reserve (ARB).

\begin{tabular}{|c|c|}
\hline Topic & Example questions \\
\hline \multirow{4}{*}{$\begin{array}{l}\text { 1) Participants' profile and relationship } \\
\text { with the } A B R\end{array}$} & Position and profile (engineer, geographer, ...)? \\
\hline & How many years lived in the ABR? \\
\hline & What are your activities related to the ABR? \\
\hline & How many years of experience? In which field(s)? \\
\hline \multirow[t]{2}{*}{ 2) Participants' own definition of BR } & What do you know about Biosphere Reserves in general? What is their main interest? \\
\hline & What is the Arganeraie Biosphere Reserve for you? \\
\hline \multirow[t]{4}{*}{$\begin{array}{l}\text { 3) State of the art of the ABR. Territory } \\
\text { and institutional management }\end{array}$} & $\begin{array}{l}\text { Could you briefly describe the current state of the ABR (e.g. actors, realities, challenges, opportu- } \\
\text { nities, responsibilities, dynamics)? }\end{array}$ \\
\hline & As far as you know, what are the governing bodies of the ABR? \\
\hline & Is there an ABR's management committee? Is it active? \\
\hline & Management criteria in the different zones (transition, buffer, central)? \\
\hline \multirow{3}{*}{$\begin{array}{l}\text { 4) Perceptions of governance in the } A B R \text {. } \\
\text { Is the zoning respected? In which zone } \\
\text { ( } A, B \text { or } C \text { ) is it respected? }\end{array}$} & In your opinion, what can be done to improve management if necessary? \\
\hline & Who are the actors most concerned by the ABR? and the beneficiaries? \\
\hline & Is there an actor(s) who is(are) absent from the ABR and whose presence is important? \\
\hline
\end{tabular}

the ABR governance (Table 2). The criteria used to select participants at the national, regional and subregional level were: (1) people closely involved in any of the three ABR main historical periods and (2) a purposive sample of $\mathrm{ABR}$ main actors covering the governance structures linked to the ABR and relevant research institutions. Thus the 42 in-depth interviews addressed the research topics and helped to grasp nuances, contradictions and a wide range of representative perspectives.

Participant observation contributed to detecting inconsistencies in contradictory information in the in-depth interviews, to assessing the quality of the information received (e. g. social pressure to respond even when respondents do not know the answer) and to identifying informal relationships and other hidden key elements.

\section{Data analysis}

Results come from the joint coding and analysis of all the field data obtained (i.e. interviews' transcriptions and on-field notes). The data were analysed by means of the Nvivo12 software for coding social research data) following constructivist analytic methods
Legend

- ABR key actors

Connection strength

- Academia

- Cooperation institution

- National NGO

- National administration

- Regional administration

- Regional institution

- Regional NGO

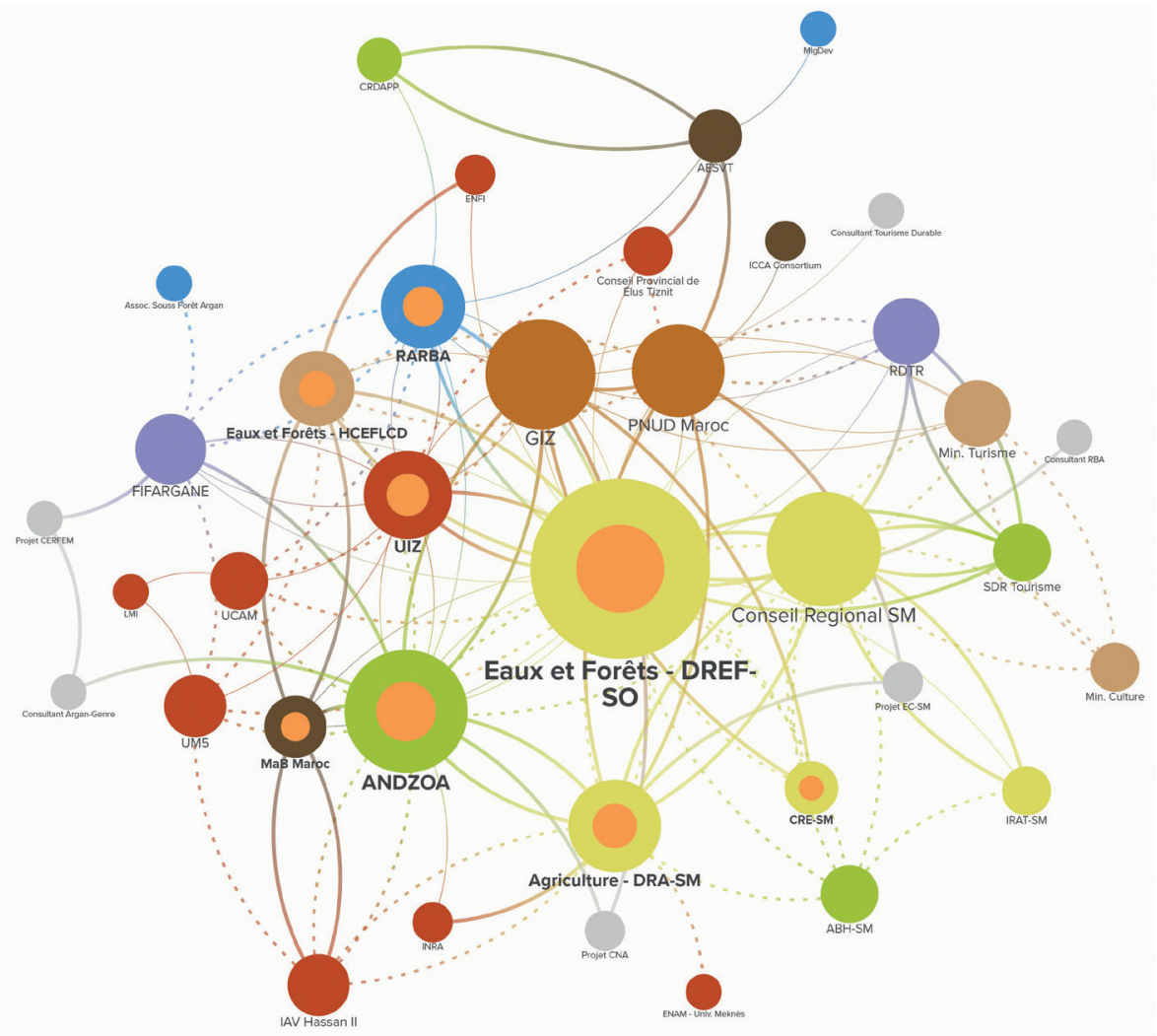

Figure 1 - Arganeraie Biosphere Reserve (ARB) institutional actors' map. Relations and degree of centrality among the institutional actors directly linked with the ARB in 2019 (Kumu 2020). *For further detail on actors, see Table 3. 
Table 3 - Arganeraie Biosphere Reserve (ARB) main actors' acronyms and full names.

\begin{tabular}{|c|c|c|}
\hline Key actor acronym & Full French name & Full English name \\
\hline ABH-SM & Agence de Basin Hydraulique Souss-Massa & Water Basin Agency of Souss-Massa \\
\hline AESVT & $\begin{array}{l}\text { Association d'Enseignants de Sciences de Vie et de } \\
\text { la Terre }\end{array}$ & Association of Life and Earth Sciences Professors \\
\hline Agriculture DRA-SM & Direction Régionale de l'Agriculture Souss-Massa & $\begin{array}{l}\text { Regional Department of Agriculture, Ministry of } \\
\text { Agriculture }\end{array}$ \\
\hline ANDZOA & $\begin{array}{l}\text { Agence Nationale de Développement des Zones des } \\
\text { Oasis et de l'Arganier }\end{array}$ & $\begin{array}{l}\text { National Agency for Development of Oasis Zones } \\
\text { and the Arganeraie }\end{array}$ \\
\hline Communes & Commune territorial & Local administration \\
\hline Conseil Régional SM & Conseil de la Région de Souss-Massa & Souss Massa Regional Council \\
\hline Culture & Direction Régional de la Culture & Regional Delegation of Culture \\
\hline DRE-SM & Direction Régionale de l'Environnement Souss-Massa & $\begin{array}{l}\text { Regional Department of the Environment, Ministry of } \\
\text { Environment }\end{array}$ \\
\hline Equx-et-Forêts DLCDPN/DEF & $\begin{array}{l}\text { Division des Parcs et Réserves naturelles. Haut-Com- } \\
\text { missariat aux Eaux et Forêts et de la Lutte Contre la } \\
\text { Désertification (HCEFLCD) }\end{array}$ & $\begin{array}{l}\text { Parks and Natural Reserves Division. Department of } \\
\text { Water and Forest, Ministry of Agriculture }\end{array}$ \\
\hline Eaux-et-Forêts DREFLCD-SO & $\begin{array}{l}\text { Direction Régionale des Eaux et Forêts et de la Lutte } \\
\text { Contre la Désertification Sud-Ouest }\end{array}$ & $\begin{array}{l}\text { Regional Department of Water and Forest, South- } \\
\text { West }\end{array}$ \\
\hline Education CRDAPP & $\begin{array}{l}\text { Centre Régional de Documentation, d'animation et } \\
\text { de Production Pédagogique }\end{array}$ & $\begin{array}{l}\text { Regional Centre for Documentation, Animation and } \\
\text { Pedagogical Production, Ministry of Education }\end{array}$ \\
\hline FIFARGANE & Fédération Interprofessionnelle de la Filière Argan & Inter-Professional Federation of the Argan Sector \\
\hline GIZ & GIZ - Coopération allemande & GIZ - German Cooperation \\
\hline IAV & Institute Agronomique et Vétérinaire & Agronomic and Veterinary Institute \\
\hline INRA & Institut National de Recherche Agricole & National Institute of Agrarian Research \\
\hline IRAT-SM & $\begin{array}{l}\text { Inspection Régional de l'Aménagement de Territoire } \\
\text { Souss-Massa }\end{array}$ & Regional Inspection of Territorial Planning \\
\hline MaB Maroc & MAB Comité au Maroc & Man and the Biosphere (MAB) Committee in Marocco \\
\hline PNUD Maroc & PNUD Maroc & UNDP Morocco \\
\hline Provinces & Province et préfecture & Intra-regional administration \\
\hline RARBA & $\begin{array}{l}\text { Réseau des Associations de la Réserve de Biosphère } \\
\text { de l'Arganeraie. }\end{array}$ & $\begin{array}{l}\text { Network of Associations of the Arganeraie Biosphere } \\
\text { Reserve }\end{array}$ \\
\hline RDTR & $\begin{array}{l}\text { Réseau de Développement du Tourisme Rural Souss } \\
\text { Massa }\end{array}$ & Souss Massa Rural Tourism Development Network \\
\hline Tourism-e & Direction Régional du Tourisme & Regional Delegation of Tourism \\
\hline UIZ & Université lbn Zohr & Ibn Zohr University \\
\hline Wilaya & Wilaya d'Agadir Ida Outanane & Regional administration, Ministry of Interior \\
\hline
\end{tabular}

(Charmaz 2014), iteratively integrating both inductive and deductive approaches.

A comprehensive social analysis was conducted in two stages. First, through stakeholder identification and mapping (actor's map) using the relationship mapping software Kumu (Kumu 2020) and data collected from prospective interviews, the two last questions in Table 2 and field notes from participant observation. Second, through an in-depth analysis of the relationships of collaboration and/or conflict, legitimacy, interest and power (i.e. CLIP descriptors) existing among actors linked to the ABR; and measured following the CLIP methodology as described in (Chevalier \& Buckles 2008) with data from participant observation and in-depth interviews.

The degree of centrality is a Kumu's Social Network Analysis metric, representing the total value of each actor's connections, that is, each actor's weighted number of connections with other actors regarding the ABR. Additionally, key actors here are those with a maximum degree of influence (on a $0 /$ minimum - 6/maximum scale) regarding the ABR decisionmaking.

\section{Results}

Social analysis I. Stakeholder identification and mapping

To properly analyse what is happening in the ABR in terms of institutional environmental governance, the authors first analysed who has a say within the ABR (Reed et al. 2009) and who was included as an institutional actor in the ABR (Table 3). According to the sampling design, the set of participants' profiles adequately reflects the broader community of $\mathrm{ABR}$ institutional actors.

An initial institutional actors' map of the ABR (Figure 1) shows a simplified multi-scale diagnosis of the extended peer community of decision-makers, including their connections, degree of centrality to the network and actors' profiles. Results unveil how out of the 24 main actors identified in the ABR (Table 3), just seven reach a high level of centrality, and only eight may be considered key actors, which means that a big gap exists between the number of officially recognized institutional actors and their real implication and influence. Figure 1 reveals that 1) regional NGOs and other social actors are underrepresented; and 2) relevant regional and local institutional actors are absent in prac- 

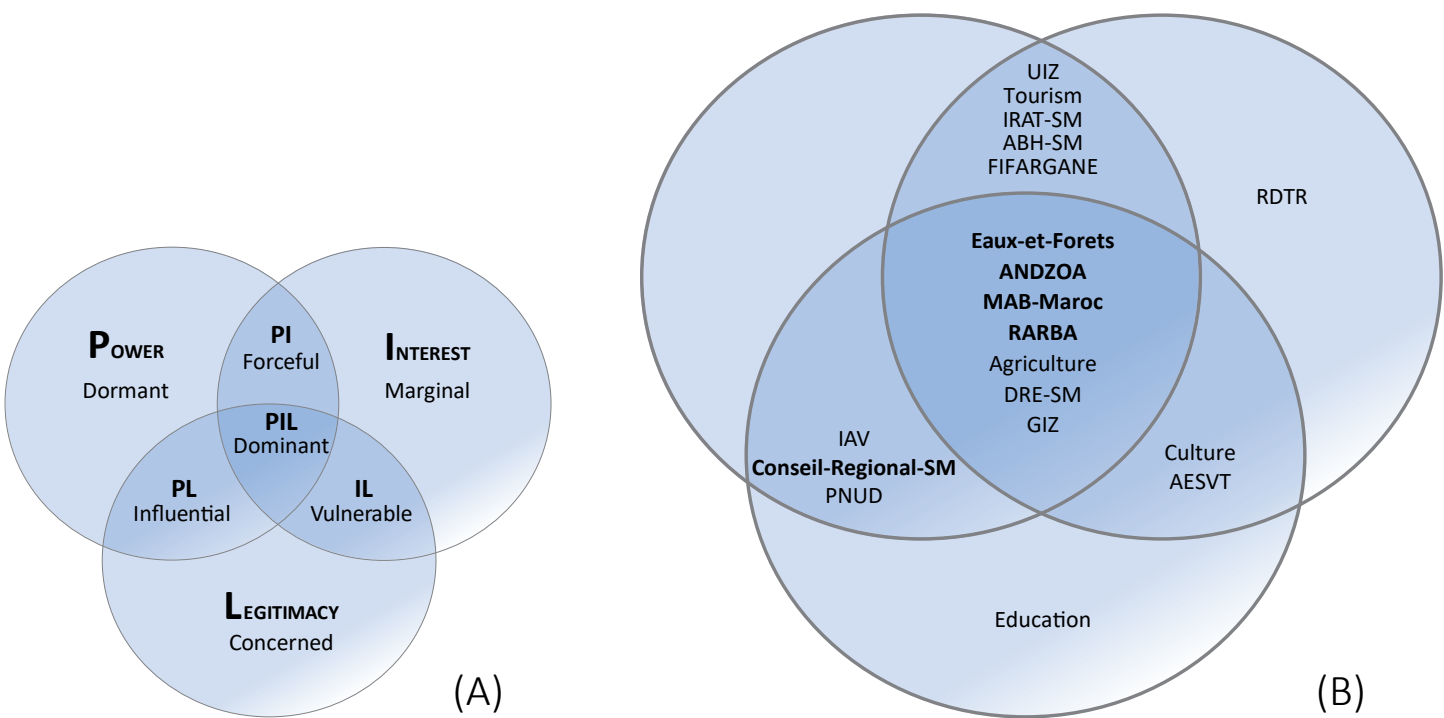

Figure 2 - (A) Venn diagram showing the relations between the various CLIP descriptors adapted from Chevalier Buckles (2008). (B) Venn diagram classifying the main Arganeraie Biosphere Reserve (ARB) institutional actors using the CLIP method. *For further detail on actors, see Table 3.

tice (i.e. provinces, communes, Wilaya), while others are dormant most of time (i. e. Conseil Regional, $\mathrm{MaB}$ Maroc, CRE-SM, Culture, Tourism).

Social analysis II. Power, interests, legitimacy, collaboration and conflict

To adequately describe and analyse the characteristics and relationships of the ABR institutional actors previously identified (see Figure 1), we characterized them according to their legitimacy, power, interests and relationships of collaboration and/or conflict (i. e. CLIP descriptors). Figure 2 illustrates the result of a comprehensive CLIP social analysis in which each CLIP descriptor has been divided into its component parts. The authors deemed it necessary and insightful, given the complex and unclear governance scenario of the ABR.

Institutional management of the ABR. The theory-practice gap

An understanding of how Moroccan institutions perceive and manage the BR and the Arganeraie territory allowed us to explain why governance remains the biggest challenge in the ABR. Results based on prospective interviews and responses to the issue of institutional management (Table 2) indicate that, first, the structures in charge of the ABR are the same in charge of protected areas and state forests. Second, the National MAB Committee exists, but it is not functional enough (members are volunteers and far from the

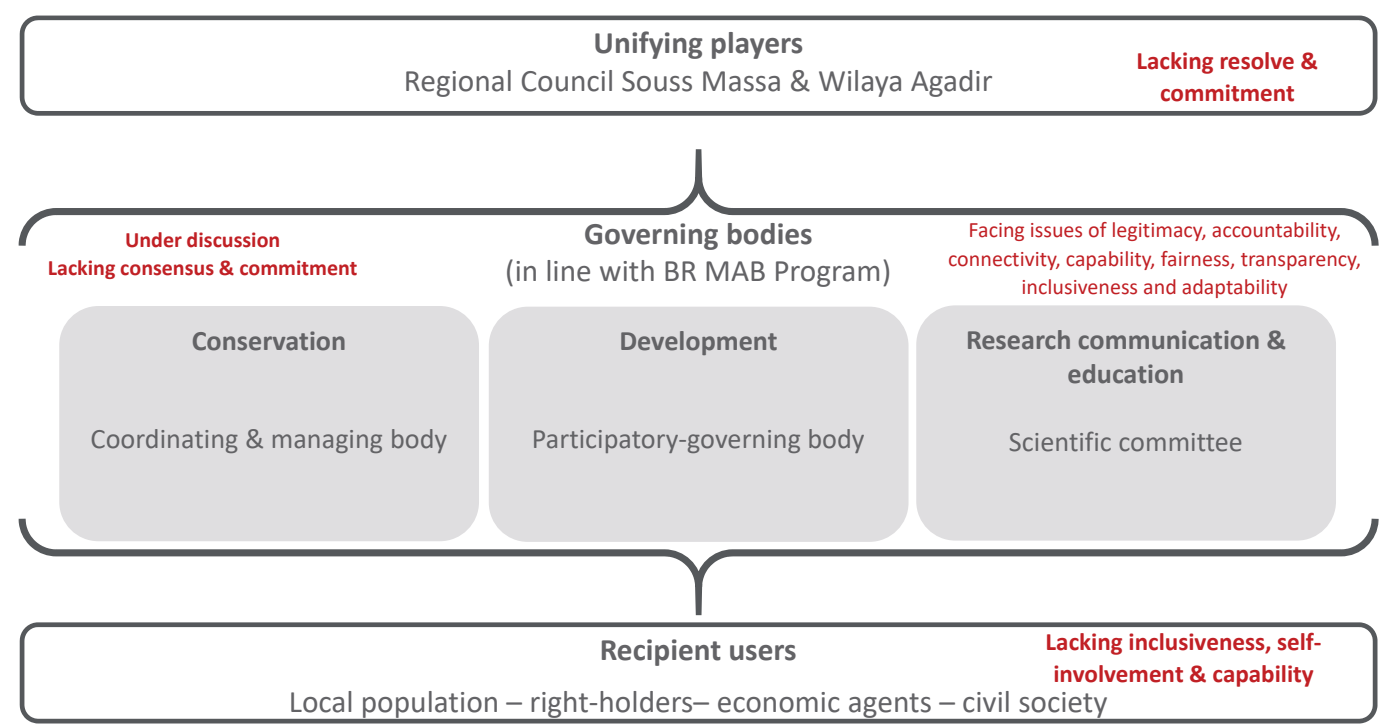

Figure 3 - Arganeraie Biosphere Reserve (ARB) official governing bodies and key stakeholders, featuring findings on their main current challenges regarding inclusive environmental governance (IEG). 


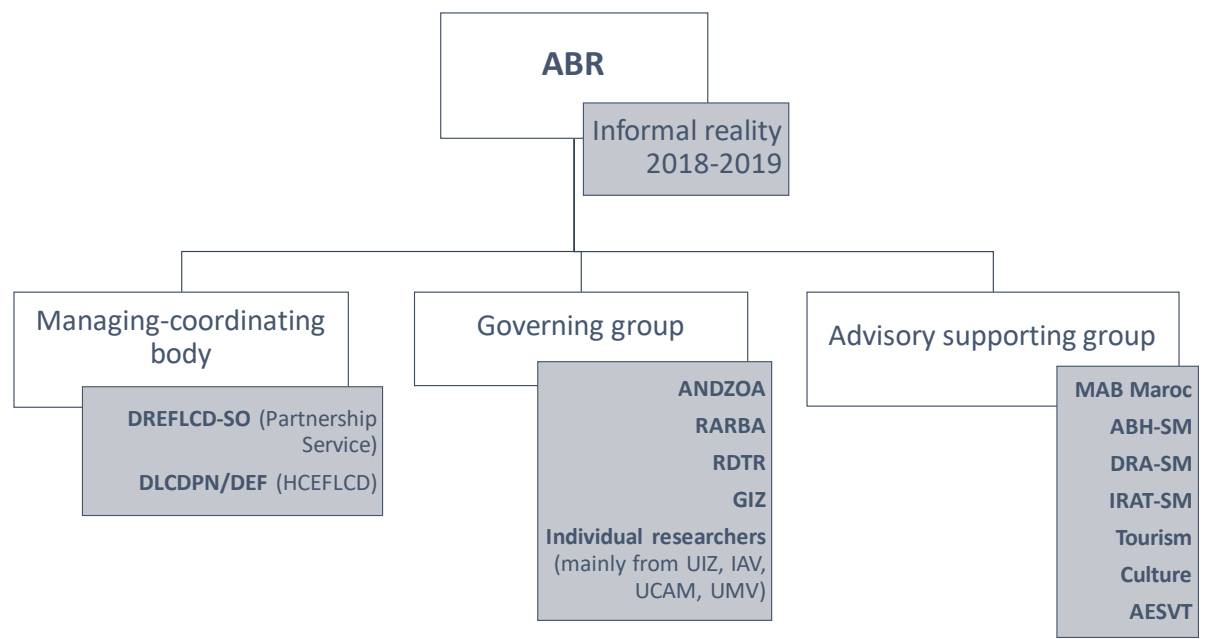

Figure 4 - Arganeraie Biosphere Reserve (ARB) informal current governing group (2018-2019). A group of leading and engaged individuals and institutions and their main current roles and responsibilities. *For further detail on actors, see Table 3.

ABR). Third, apart from the NGOs involved, local populations do not have a significant place in the management of the BR.

The management of BRs in Morocco is attributed in the national legislation to the High Commission for Water and Forests (HCEFLCD). Nevertheless, this attribution is beyond the strict competencies of the HCEFLCD and covers a vast territory. This implies the need to include all territorial components and to unite all sectoral partners in governing the ABR (DREFLCD-SO 2018). The four main findings are: first, the coordination structure set up is inoperative, acting as a supervisory structure rather than a management body; second, the ABR Framework Plan (2002) is also inoperative and there was no Action Plan until 2020; third, the ABR is institutionally managed as a Dossier with no staff officially designated to manage it; and fourth, the role of development projects has proven to be relevant within the configuration of the actor's network. Development projects have a significant influence on the ABR dynamics.

Yet, 2018-2019 was a leverage point for the ABR, starting from the $2^{\text {nd }}$ UNESCO Periodic Review, which has fuelled: (1) a communication plan, (2) the revision of zoning and limits, (3) a management plan and a regional governance workshop, where the former documents must be discussed, agreed and validated. In this regard, the new ABR Action Plan (2020) proposes various governance scenarios for debate under the structure charted in Figure 3, including the ABR's unifying players, governing bodies and users. Figure 3 shows the ABR organizational structure, featuring in red the main current challenges regarding IEG across levels, as identified in the analysis. Failure to address these challenges may result, once again, in failure to achieve an operational structure.

Findings reveal respondent's lack of clarity on the roles, mission and typology of the key ABR institutional decision-makers. Language and terminology used to name them do not help (e.g. beneficiaries, actors involved, promoters, managers, coordinators, decision-makers, etc., are terms frequently leading to confusion); neither does the effort required by some respondents to translate from their dialect into French help. In the absence of a legitimate governing body that is widely validated by all stakeholders, each of the prominent institutions tries to position itself through discourses that are sometimes contradictory to the whole institution and at other times fuelled by financial or personal interests. This situation is a major constraint on the BR's progress, fosters confusion in people and hinders effective cooperation and dialogue.

Nevertheless, positive informal dynamics and the interaction of individual and institutional actors (i.e. relationships of trust, collaboration, alliances or dialogue) also play a relevant role in the ABR, guided by their values, identities, self-responsibility, leadership, personal concerns and willpower. They might be preventing the system from failure and foster dialogue, improvement and evolution. Figure 4 shows the ABR reality derived from the field data analysis, a major strength regarding IEG.

\section{Perceptions of governance in the ABR}

Results based on participant observation, respondents' profile and their perceptions of governance in the ABR (topics 1,2 and 4 in Table 2) indicate that these perceptions are highly impacted by the individual actors' profiles, experiences and mindsets when it comes to their professional behaviours, decisions and discourses. Such impact has frequently been overlooked in the scientific literature to date.

There is a high consensus on identified weaknesses and on the need to improve the current ABR governance model, as shown in Table 4. However, most participants are convinced that it is feasible to reach a general agreement, despite current difficulties, if there is enough political will, combined with strong leader- 
Table 4 - Main generalized perceptions (outcomes) of inclusive environmental governance (IEG) in the Arganeraie Biosphere Reserve $(A R B)$ and relevant quotes supporting them. *For further detail on actors, see Table 3.

\begin{tabular}{|c|c|c|}
\hline Topic & Relevant supporting quotes & $\begin{array}{l}\text { Key outcomes towards an IEG } \\
\text { model }\end{array}$ \\
\hline \multirow[t]{7}{*}{$\begin{array}{l}\text { Vision, resolve and } \\
\text { interests }\end{array}$} & $\begin{array}{l}\text { At present: we are still discussing on paper, not in the real situation. ABR is not } \\
\text { considered in the decisions; it is not relevant. }\end{array}$ & \multirow{5}{*}{$\begin{array}{l}\text { The ABR is not widely perceived } \\
\text { as a territorial sustainable gov- } \\
\text { ernance model. } \\
\text { The ABR lacks the political and } \\
\text { social will. And the individual } \\
\text { resolve remains insufficient but } \\
\text { crucial. }\end{array}$} \\
\hline & $\begin{array}{l}\text { There is no real will on the state's side. There needs to be a real will and target- } \\
\text { ing of political actors. }\end{array}$ & \\
\hline & $\begin{array}{l}\text { There is not enough involvement at the national level ... Stakeholders are worry- } \\
\text { ing at the regional level. ABR is an opportunity. }\end{array}$ & \\
\hline & Civil society is not organzed to defend $A B R$. & \\
\hline & There is a need for political will for the regions to take the lead. & \\
\hline & $\begin{array}{l}\text { In the ABR, the focus has been on the economy and not on protection and } \\
\text { social issues. The actors are not satisfied. There are conflicts of vision between } \\
\text { agriculture [DRA-SM] and forestry [DREFLCD-SO]. There is a [dominant eco- } \\
\text { nomic] development trajectory. }\end{array}$ & \multirow[t]{2}{*}{$\begin{array}{l}\text { There is not a shared vision of } \\
\text { the development model in the } \\
\text { ABR. }\end{array}$} \\
\hline & $\begin{array}{l}\text { The challenges are to achieving good communication, to reach agreement first, } \\
{[\ldots] \text { and to reunite the interests of everyone. }}\end{array}$ & \\
\hline \multirow{6}{*}{$\begin{array}{l}\text { Accountability, leader- } \\
\text { ship and legitimacy }\end{array}$} & We need councillors who can lead the way. & \multirow{4}{*}{$\begin{array}{l}\text { Issues of leadership, will and } \\
\text { accountability are key but } \\
\text { sometimes dependent on other } \\
\text { factors like competence, interest } \\
\text { or vision. }\end{array}$} \\
\hline & $\begin{array}{l}\text { There is a need for capacity building and multi-stakeholder cooperation [con- } \\
\text { ciliation]. }\end{array}$ & \\
\hline & $\begin{array}{l}\text { There is goodwill, it is a question of leadership, leadership as action. There is a } \\
\text { lack of collective intelligence. People need to embrace the discourse. }\end{array}$ & \\
\hline & $\begin{array}{l}\text { There is a need to build the capacity of public actors and civil society repre- } \\
\text { sentatives; create opportunities for people to be involved. }\end{array}$ & \\
\hline & There is no official interlocutor recognised by everyone. & \multirow{2}{*}{$\begin{array}{l}\text { The managing body is not fully } \\
\text { accepted by all stakeholders. }\end{array}$} \\
\hline & $\begin{array}{l}\text { The governmental actors are DREFLCD-SO [official] and ANDZOA [law] [...] but } \\
\text { there is confusion on the spot. }\end{array}$ & \\
\hline \multirow[t]{9}{*}{$\begin{array}{l}\text { Governance and } \\
\text { inclusion }\end{array}$} & $\begin{array}{l}\text { The framework plan [2002] provides for regional, provincial and local commit- } \\
\text { tees, but it is not functional. }\end{array}$ & \multirow{9}{*}{$\begin{array}{l}\text { The governing body does not } \\
\text { exist or it is not functional. } \\
\text { There is a need for dialogue } \\
\text { and concertation. }\end{array}$} \\
\hline & The ABR needs to be institutionalized; it is paramount. & \\
\hline & $\begin{array}{l}\text { There are statistical data, studies, decennial reports, advances everywhere } \\
\text { except from the governing body, where there are no advances. There is the } \\
\text { managing body but not a governing body. There is no official interlocutor } \\
\text { recognized by everyone. }\end{array}$ & \\
\hline & $\begin{array}{l}\text { There is not exactly one entity that brings together all the institutions; it is } \\
\text { DREFLCD-SO that manage directly. }\end{array}$ & \\
\hline & $\begin{array}{l}\text { There is a need to raise awareness. Each one works in his own corner. First, } \\
\text { ABR needs to be institutionalized. }\end{array}$ & \\
\hline & There is a need for dialogue and institutionalization. & \\
\hline & The fundamental shortcoming is not having a managing committee. & \\
\hline & $\begin{array}{l}\text { RAABR and DREFLCD-SO are the holders of the ABR. There is no appropriation. } \\
\text { It needs to be institutionalized. }\end{array}$ & \\
\hline & The implementation of the framework plan must be done with the population. & \\
\hline \multirow[t]{6}{*}{ Law and policy } & $A B R$ must also be defined in the legal framework. & \multirow{5}{*}{$\begin{array}{l}\text { There is a need for legal } \\
\text { framework well-adapted to the } \\
\text { singularities of the BR model. }\end{array}$} \\
\hline & $\begin{array}{l}\text { BR is an institutional structure that does not exist in Moroccan law. And this is a } \\
\text { constraint [...]. }\end{array}$ & \\
\hline & $\begin{array}{l}\text { The second problem is that it [ABR] cannot even be included in the national } \\
\text { protected areas [legislation], because the BR is a category that does not exist } \\
\text { for the IUCN [...]. }\end{array}$ & \\
\hline & $\begin{array}{l}\text { It is the state that asked for the BRs, so it must be consistent and logical with } \\
\text { itself and introduce the notion of BRs in its [legal] categories. }\end{array}$ & \\
\hline & $\begin{array}{l}\text { Now we have a second text for protected areas [...] from 2014-2015 [...] and } \\
\text { even this new text does not contain references to BRs. It should therefore be } \\
\text { possible, at some point in time, to amend this text and place BRs in it. }\end{array}$ & \\
\hline & $\begin{array}{l}\text { It is necessary to look for synergies between the national sustainable develop- } \\
\text { ment strategy (2017-2030) and the ABR. Local and regional authorities } \\
\text { [regional council]. }\end{array}$ & $\begin{array}{l}\text { Deficient integration of the } \\
\text { diverse sectoral and regional } \\
\text { policies and national strategies. } \\
\text { Including the ABR. }\end{array}$ \\
\hline \multirow{5}{*}{$\begin{array}{l}\text { Information and } \\
\text { transparency }\end{array}$} & Access to information is a major issue [the importance of the unsaid]. & \multirow{4}{*}{$\begin{array}{l}\text { Transparency, access to and in- } \\
\text { formation sharing are major is- } \\
\text { sues that need to be addressed. }\end{array}$} \\
\hline & $\begin{array}{l}\text { Communication and consultation must be institutionalized. And each one must } \\
\text { find its own interest. }\end{array}$ & \\
\hline & An information-sharing system must be set up. & \\
\hline & $\begin{array}{l}\text { It is also necessary to be transparent and open with the population, [...] [to } \\
\text { promote] discussion platforms at the level of rural communes and a great effort } \\
\text { of mediation and confidence-building. }\end{array}$ & \\
\hline & And do not forget the role of the media. There is not enough communication. & The relevant role of the media. \\
\hline \multirow[t]{2}{*}{$\begin{array}{l}\text { Languages and } \\
\text { concepts }\end{array}$} & $\begin{array}{l}\text { It is key agreeing on definitions of management and governance for each actor } \\
\text { [organisation and/or individual]. }\end{array}$ & \multirow{2}{*}{$\begin{array}{l}\text { There is a need for a shared } \\
\text { language among the main } \\
\text { stakeholders. }\end{array}$} \\
\hline & The challenges are $[\ldots]$ to reunite the definitions of each one. & \\
\hline
\end{tabular}




\begin{tabular}{|c|c|c|}
\hline Topic & Relevant supporting quotes & $\begin{array}{l}\text { Key outcomes towards an IEG } \\
\text { model }\end{array}$ \\
\hline \multirow{4}{*}{$\begin{array}{l}\text { Languages and } \\
\text { concepts }\end{array}$} & Secondly, the concept of $A B R$ needs to be appropriated. & \multirow{4}{*}{$\begin{array}{l}\text { The concept and model of MAB- } \\
\text { BR need to be widely understood } \\
\text { and appropriated. }\end{array}$} \\
\hline & $\begin{array}{l}\text { There is a need to ... promote knowledge of ABR so that the concept is ap- } \\
\text { propriated. }\end{array}$ & \\
\hline & There is a lack of collective intelligence. People need to embrace the discourse. & \\
\hline & $\begin{array}{l}\text { Local people are detached from the term [BR] but not from the action for the } \\
A B R \text {. }\end{array}$ & \\
\hline
\end{tabular}

ship. All of them consider the ABR a great opportunity and the future for the region; as someone literally stated: "The Arganeraie Biosphere Reserve in the future is a major opportunity and an imperative for Morocco internationally ... There is no room for error".

\section{Discussion}

Evidence sheds light on the formal and informal actors' network and perspectives on governance in the ABR. It has allowed clarifying the current main dynamics and challenges for IEG in the ABR. Results are consistent and reinforce previous research in the field globally (Stoll-Kleemann 2007; Schultz et al. 2011; van Cuong et al. 2017) regarding factors influencing the success or failure of BRs. Furthermore, the ethnographic approach has uncovered several of the factors underlying these successes and failures, such as personal interests, values, identity, etc. (enablers for IEG in Table 6).

The ABR case study also permits testing the consistency of the findings (Table 5) with previous research on the main challenges for IEG and management of other North African BRs (Table 1). Table 5 shows how these challenges are the same between the ABR and other North African BRs (convergences are marked in bold).

Given the qualitative evidence, the authors summarize in Table 6: (1) the various baseline needs and constraints that must be addressed in advance, failure to do so will hamper governance; (2) some key points to improve current governance; and (3) a set of enablers to foster IEG in the ABR. We argue that, even in contexts where not even the basic principles of good governance (Lockwood 2010) are present, informal dynamics and relations between actors (as unveiled in Figure 4) can build a certain level of resilience that prevents the system from collapsing and sets the basis for improvement, adaptation and evolution, given a favourable context. At this point, paying attention to individuals' frameworks of ideas, values, motivations, mindsets, interests, etc. (as suggested by Armitage et al. (2011), Tengö et al. (2014) or Buschke et al. (2019), among others) is paramount as institutions are ultimately made up of individuals.

\section{Conclusion}

Establishing and maintaining inclusive environmental governance (IEG) across the diversity of actors, relationships, territorial dynamics and responsibility arrangements is critical for the future effectiveness and appropriation of BRs by their stakeholders and communities. By understanding actors' perceptions and why they behave as they do, decision-makers will be better positioned to detect synergies that allow for a shared vision and thus for a proper strategy of their territory. Present research and, specifically, the ABR case study have focused on the former, contributing to one of the main weaknesses of BRs worldwide: the practice-theory gap. The authors have done so in a region that is seriously under-represented in the scientific literature published in the field (i.e. North Africa, Maghreb), despite being one of UNESCO's strategic priority regions globally (UNESCO 2014, p. 6). The ethnographic approach has allowed us to grasp indepth crucial factors, such as individuals' frameworks of ideas, values, motivations, mindsets or interests.

Table 5 - Main challenges in the implementation of inclusive environmental governance (IEG) in the Arganeraie Biosphere Reserve (ARB). Convergences with other North African biosphere reserves (BRs) marked in bold.

\begin{tabular}{|l|}
\hline ARB case study \\
\hline Insufficient political support. Lack of a shared vision (multi-level and multi-actor) \\
\hline Absence of a governing body. Establishment of management and/or coordination structures dedicated to (BRs ) \\
\hline Insufficient coordination (multi-level and multi-actor) \\
\hline Insufficient capacity and resources (multi-level) \\
\hline Understanding and differentiation of the BR concept. Appropriation of the BR and the BR concept (multi-level and multi-actor) \\
\hline $\begin{array}{l}\text { Involvement and participation of local communities. Poor integration of local communities in management. Lack of appropriation of } \\
\text { the BR }\end{array}$ \\
\hline Poor implementation of the Framework Plan and lack of an Action Plan \\
\hline Inappropriate legal framework \\
\hline Lack of functionality of zoning. It is unknown to most actors \\
\hline Interface policy-research. Lack of social research \\
\hline Lack of awareness and poor communication (multi-level and multi-actor) \\
\hline
\end{tabular}


Table 6 - Factors infuencing inclusive environmental governance (IEG) in the Arganeraie Biosphere Reserve (ARB): baseline needs and constraints, key aspects for improvement and enablers of inclusive governance.

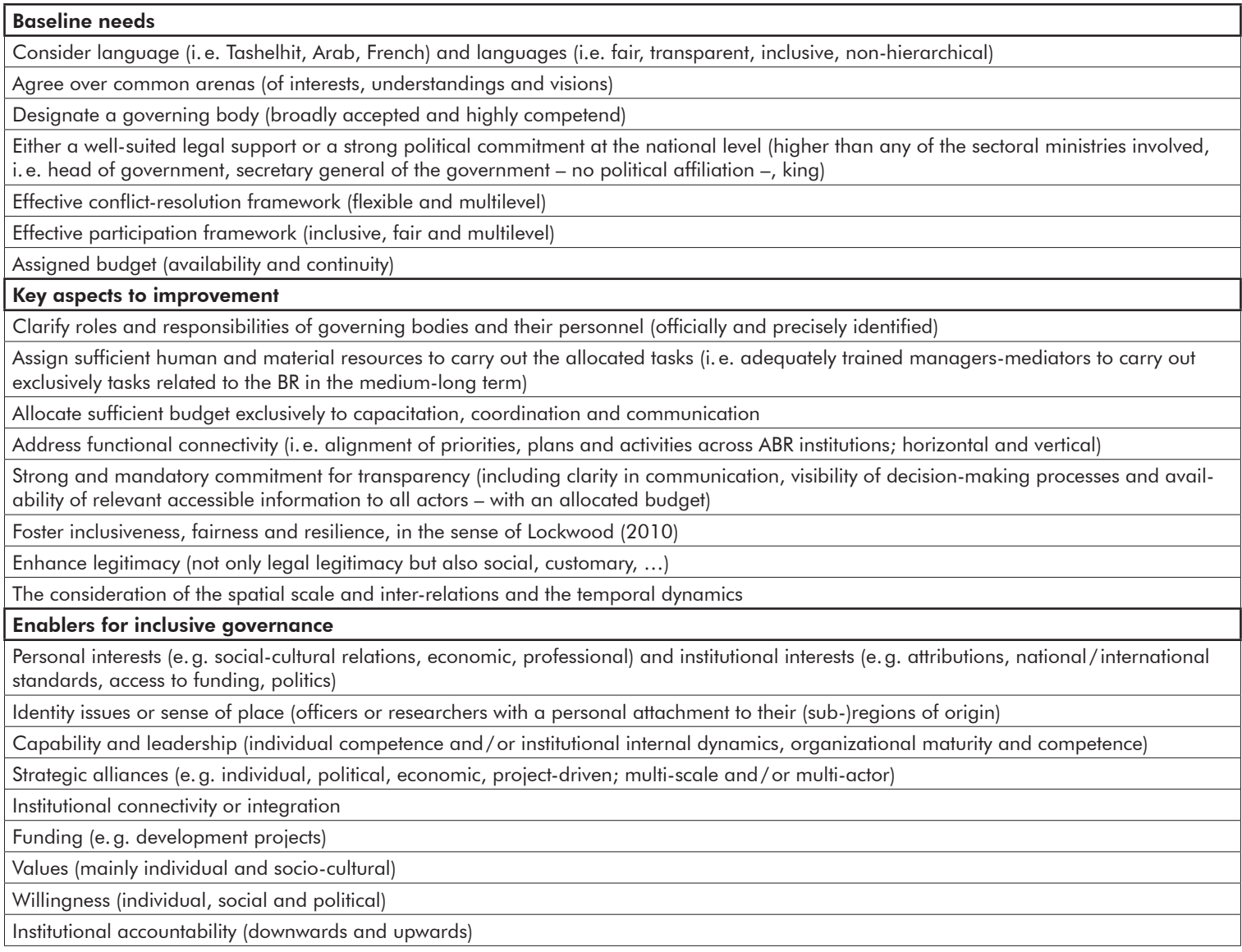

Stakeholder identification and mapping have shown the complex network of actors in the ABR and the big gap between the officially recognized institutional actors and their real presence and role. Results from the CLIP analysis and the institutional management of the ABR have evidenced the theory-practice gap, how and why CLIP descriptors shape reality and contribute to the gap, and the highly diverse outlook of formalinformal relations and their great relevance. The identified baseline needs, constraints and key aspects for improvement suggest various policy-research recommendations. The ABR is perceived as a great opportunity for most actors and IEG is thought feasible. However, enough political will and strong leadership are a must. The role and scope of informal dynamics and interrelations among actors are essential in the ABR, and their contribution is vital to its resilience.

Overall, our results provide clues and invite a reframing of IEG, not as a goal but as a precondition to addressing factors influencing the success or failure of BRs that are widely acknowledged in the literature and confirmed in the ABR case study. Individuals' frameworks of ideas, values, motivations, mindsets and interests are, indeed, strongly linked to all the enablers of IEG identified in this study and deserve further attention from both policy-makers and the scientific community. Furthermore, as institutions are ultimately made up of individuals, ethnographic and holistic approaches are apt to uncover many of the underlying hidden factors that have been overlooked to date.

\section{References}

Armitage, D., F. Berkes, A. Dale, E. Kocho-Schellenberg \& E. Patton 2011. Co-management and the co-production of knowledge: Learning to adapt in Canada's Arctic. Global Environmental Change: 995-1004.

Batisse, M. 1982. The Biosphere Reserve: A Tool for Environmental Conservation and Management. Environmental Conservation 9: 101. Doi: 10.1017/ S0376892900019937

Beier, P., L.J. Hansen, L. Helbrecht \& D. Behar 2017. A How-to Guide for Coproduction of Actionable Science. Conservation Letters 10: 288-296. Doi: $10.1111 /$ conl. 12300

Berkes, F., J. Colding \& C. Folke 2003. Navigating socialecological systems: building resilience for complexity and change. Cambridge, UK. Doi: 10.1016/j.biocon.2004.01.010

Blanco, J., B. Bellón, C. Fabricius, F. de O. Roque, O. Pays, F. Laurent, H. Fritz \& P.C. Renaud 2020. Interface processes between protected and unprotected 
areas: A global review and ways forward. Global Change Biology 26: 1138-1154. Doi: 10.1111/gcb.14865

Borrini-Feyerabend, G., N. Dudley, T. Jaeger, B. Lassen, N. Pathak Broome, A. Phillips \& T. Sandwith 2013. Governance of Protected Areas: From understanding to action. Best Practice Protected Area Guidelines Series No. 20. Gland, Switzerland.

Brunson, M.W. 2012. The elusive promise of social-ecological approaches to rangeland management. Rangeland Ecology and Management 65: 632-637. Doi: 10.2111/REM-D-11-00117.1

Buschke, F.T., E.A. Botts \& S.P. Sinclair 2019. Postnormal conservation science fills the space between research, policy, and implementation. Conservation Science and Practice 1. Doi: 10.1111/csp2.73

Charmaz, K. 2014. Constructing grounded theory (Second edition).

Chevalier, J.M. \& D.J. Buckles 2008. SAS2: a Guide to Collaborative Inquiry and Social Engagement.

Coetzer, K.L., E.T.F. Witkowski \& B.F.N. Erasmus 2013. Reviewing Biosphere Reserves globally: effective conservation action or bureaucratic label? Biological Reviews 89: 82-104. Doi: 10.1111/brv.12044

DREFLCD-SO 2018. Evaluation Décennale de la Réserve de Biosphère de l'Arganeraie 2008-2017. Agadir. Morocco.

DREFLCD-SO 2020. Elaboration du Nouveau Plan d'Action de la ABR 2018-2027. Agadir. Morocco.

Folke, C., T. Hahn, P. Olsson \& J. Norberg 2005. Adaptive Governance of Social-Ecological Systems. Annual Review of Environment and Resources 30. Annual Reviews: 441-473. Doi: 10.1146/annurev. energy.30.050504.144511

Funtowicz, S.O. \& J.R. Ravetz 1993. Science for the post-normal age. Futures 25. Pergamon: 739-755. Doi: 10.1016/0016-3287(93)90022-L

Gunderson, L.H. \& C.S. Holling 2002. Panarchy: understanding transformations in buman and natural systems. Washington D.C.

HCP 2014. Recensement Général de la Population et de l'Habitat de 2014 an Maroc (RGPH 2014). Available at: https://www.hcp.ma/RGPH-2014_r230.html (accessed: 06/09/2021)

Heinrup, M. \& L. Schultz 2017. Swedish Biosphere Reserves as Arenas for Implementing the 2030 Agenda.

Holling, C.S. 2001. Understanding the Complexity of Economic, Ecological, and Social Systems. Ecosystems 4: 390-405. Doi: 10.1007/s10021-001-0101-5

Holmes, C.M. 2008. Navigating the Socioecological Landscape. Conservation Biology 15: 1466-1467. Doi: 10.1111/j.1523-1739.2001.01552.x

Ishwaran, N., A. Persic \& N.H. Tri 2008. Concept and practice: the case of UNESCO biosphere reserves. International Journal of Environment and Sustainable Development 7: 118-131. Doi: 10.1504/IJESD.2008.018358

Ison, R.L. \& P.J. Wallis 2017. Mechanisms for Inclusive Governance. In: Meissner, R., S. Stuart-Hill \& Z. Nakhooda (eds.), Freshwater Governance for the 21st Century 6: 129-143. Doi: 10.1007/978-3-319-43350-9
IUCN 2015. Análisis Comparado de las Reservas de la Biosfera del Mediterráneo: Hacia un fortalecimiento de la cooperación y las oportunidades de aprendizaje. Informe final.

Kumu. 2020. Relationship mapping software. Available at: https://kumu.io/ (accessed 06/09/2021)

Lemos, M.C. \& A. Agrawal 2006. Environmental Governance. Annual Review of Environment and Resources 31: 297-325. Doi: 10.1146/annurev. energy.31.042605.135621

Lockwood, M. 2010. Good governance for terrestrial protected areas: A framework, principles and performance outcomes. Journal of Environmental Management 91: $\quad 754-766 . \quad$ Doi: $10.1016 / j$. jenvman.2009.10.005

Matar, D. 2015. Status of concept implementation and management effectiveness of Biosphere Reserves in the Arab region. Central European University. Budapest.

Michon, G., D. Genin, M. Alifriqui, B. Romagny, S. Boujrouf, M. Sabir \& L. Auclair 2015. Derrière l'huile d'argan, la forêt d'arganiers: écosystème en péril ou terroirs forestiers domestiques? In: Berriane, M. \& G. Michon (eds.), Terroirs Méditerranéens.

Moon, K., V.M. Adams \& B. Cooke 2019. Shared personal reflections on the need to broaden the scope of conservation social science. People and Nature 1:426434. Doi: $10.1002 /$ pan3.10043

Price, M.F., J.J. Park \& M. Bouamrane 2010. Reporting progress on internationally designated sites: The periodic review of biosphere reserves. Environmental Science \&o Policy 13: 549-557. Doi: 10.1016/j.envsci.2010.06.005

Reed, M.S., A. Graves, N. Dandy, H. Posthumus, K. Hubacek, J. Morris, C. Prell, C.H. Quinn \& L.C. Stringer 2009. Who's in and why? A typology of stakeholder analysis methods for natural resource management. Journal of Environmental Management 90: 1933-1949. Doi: 10.1016/J.JENVMAN.2009.01.001

Rose, D. 2018. Avoiding a Post-truth World: Embracing Post-normal Conservation. Conservation and Society 16: 518. Doi: 10.4103/cs.cs_17_131

Schultz, L., A. Duit \& C. Folke 2011. Participation, Adaptive Co-management, and Management Performance in the World Network of Biosphere Reserves. World Development 39: 662-671. Doi: 10.1016/j.worlddev.2010.09.014.

Stoll-Kleemann, S. 2007. Success Factors for Biosphere Reserve Management. Journal of the German Commission for UNESCO. UNESCO Biosphere Reserves: Model Regions with a Global Reputation 2: 37-39.

Tengö, M., E.S. Brondizio, T. Elmqvist, P. Malmer \& M. Spierenburg 2014. Connecting diverse knowledge systems for enhanced ecosystem governance: the multiple evidence base approach. Ambio 43: 579-591. Doi: 10.1007/s13280-014-0501-3

UNESCO 2014. UNESCO Medium-Term Strategy 2014-2021. Paris.

van Cuong, C., P. Dart \& M. Hockings 2017. Biosphere reserves: Attributes for success. Journal of 
Environmental Management 188: 9-17. Doi: 10.1016/j. jenvman.2016.11.069.

Walker, R.T. \& W.D. Solecki 1999. Managing Land Use and Land-Cover Change: The New Jersey Pinelands Biosphere Reserve. Annals of the Association of American Geographers 89: 220-237. Doi: 10.1111/14678306.00143 .

\section{Authors}

Mari-Carmen Romera ${ }^{1,5}$

is a socio-environmental scientist interested in rural commons, community-conserved and protected areas, and political ecology issues in the Mediterranean. She's a $\mathrm{PhD}$ candidate at ICTA-UAB (LASEG research group), working on ICCAs, inclusive governance and biosphere reserves in Morocco. E-mail: mariadelcarmen.romera@uab.cat

\section{Feliu López-i-Gelats²}

is a lecturer and researcher at Agroecology and Food Systems Chair in University of Vic-Central University of Catalonia (Uvic-UCC) He holds a $\mathrm{PhD}$ in Environmental Science. His research interests revolve around socioecological systems, global environmental change, adaptation, vulnerability, pastoralists, smallholders, beekeepers. E-mail: feliu.lopez@uvic.cat

Pablo Dominguez ${ }^{1,3,4}$

is a CNRS Senior Researcher at GEODE Laboratory, a LASEG-ICTA-UAB and AHCISP-ASiC-UABLinked Researcher and an Associated Researcher of LPED (UMR-151 IRD-AMU). He holds a PhD in social anthropology and ethnology (EHESS \& UAB) and a BSc in environmental biology (UAM). E-mail: eco.anthropologies3@gmail.com

\section{Said Boujrouf ${ }^{5}$}

is a Senior Researcher and Director of LERMA. Senior Professor of Geography and former Director of the Geography Department. He studied manage- ment and territorial development in Morocco. His research fields: specification, qualification, patrimonial and tourist exploitation in marginal Southern-Morocco areas. E-mail: boujrouf@yahoo.fr

\section{Roser Maneja $a^{6,7}$}

is Deputy Research Director at CTFC (Forest Science and Technology Centre of Catalonia) and Associated Professor in the Geography Department (UAB). She holds a PhD in environmental science. Her research fields: natural areas (biosphere reserves), environment-health, and bio-economy and governance. E-mail: roser.maneja@uab.cat

${ }^{1}$ Institute of Environmental Science and Technology (ICTA-LASEG), Autonomous University of Barcelona (UAB), Z Building, ICTA-ICP, Carrer de les columnes, UAB Campus, 08193 Bellaterra (Cerdanyola del Vallès), Barcelona, Spain

2 Agroecology and Food Systems Chair, Faculty of Sciences and Technology, University of Vic- Central University of Catalonia, C/de la Laura 13, 08500 Vic, Catalonia, Spain

3 Laboratory of Environmental Geography (GEODE), UMR-5602 CNRS University of Toulouse 5, Allées Antonio-Machado, 31058 Toulouse Cedex, France

${ }^{4}$ Social and Cultural Anthropology Department (AHCISP), Autonomous University of Barcelona (UAB), UAB Campus 08193, Bellaterra (Cerdanyola del Vallès), Barcelona, Spain

${ }^{5}$ Resources, Mobility and Attractivity Studies Laboratory (LERMA), Geography Department (FLSH) Cadi Ayyad University, 40000 Marrakech, Morocco

6 Geography Department, Autonomous University of Barcelona (UAB), UAB Campus 08193, Bellaterra (Cerdanyola del Vallès), Barcelona, Spain

${ }^{7}$ Forest Science and Technology Centre of Catalonia (CTFC), Ctra. de St. Llorenç de Morunys, km 2, 25280, Solsona, Spain 